\title{
Oligomer procyanidins (F2) isolated from grape seeds inhibits tumor angiogenesis and cell invasion by targeting HIF-1 $\alpha$ in vitro
}

\author{
HONG LI ZHENG ${ }^{1,3}$, JINGYU YANG ${ }^{1,3}$, YUE HOU ${ }^{1,3}$, BAOSHAN SUN ${ }^{2,4}$, \\ QINGCHUN ZHANG $^{1}$, YANHUA MOU ${ }^{1}$, LIHUI WAND ${ }^{1,3}$ and CHUNFU WU ${ }^{1,3}$ \\ Departments of ${ }^{1}$ Pharmacology and ${ }^{2}$ Drug Analysis, Shenyang Pharmaceutical University, Shenhe District, \\ 110016 Shenyang; ${ }^{3}$ Benxi Institute of Shenyang Pharmaceutical University, 177005 Benxi, P.R. China; \\ ${ }^{4}$ Grape and Wine Institute, National Institute of Biological Resources, 2560 Porto, Portugal
}

Received August 6, 2014; Accepted September 11, 2014

DOI: 10.3892/ijo.2014.2744

\begin{abstract}
Overexpression of hypoxia-inducible factor-1 (HIF-1) $\alpha$, a transcription factor which immortalizes tumors by inducing expression of the genes involved in cell survival, migration and angiogenesis, is closely associated with poor prognosis, increased risk of metastasis and increased mortality. Oligomer procyanidins (F2), a natural fraction from grape seeds, has been demonstrated to have antioxidant and antitumor activities, however the antitumor effect of F2 targeting HIF-1 $\alpha$ remains unknown. The present study showed that F2 markedly decreased HIF-1 $\alpha$ and the expression of its target genes in cancer cells through inactivating the EGFRPI3K-AKT-mTOR and MAPK-ERK1/2 pathways. Moreover, F2 suppressed vascular endothelial growth factor (VEGF) and matrix metalloproteinases (MMP)-2 expressions, followed by the inhibition of tumor angiogenesis and cell invasion in a HIF-1 $\alpha$-dependent manner. Collectively, these findings indicate that the antitumor effect of F2 is, at least in part, mediated by suppressing HIF- $1 \alpha$-dependent pathway, and suggest that F2 may be a potentially useful agent for treatment of human cancer.
\end{abstract}

\section{Introduction}

Solid tumors characteristically contain areas of hypoxia (low oxygen tension), which is a powerful stimulus for the expression of genes involved in proliferation, glycolysis, invasion and angiogenesis. Adaptation of tumor cells to hypoxic environment results in an aggressive and metastatic cancer phenotype that is associated with resistance to radiation therapy, chemotherapy, and a poor treatment outcome (1).

Correspondence to: Professor Chunfu Wu or Professor Jingyu Yang, Department of Pharmacology, Shenyang Pharmaceutical University, Box 31, 103 Wenhua Road, 110016 Shenyang, P.R. China

E-mail: wucf@syphu.edu.cn

E-mail: yangjingyu2006@gmail.com

Key words: F2, hypoxia, HIF-1 $\alpha$, angiogenesis, invasion
The transcription factor hypoxia-inducible factor-1 (HIF-1) is central to the regulation of a number of hypoxia-activated genes and consists of HIF- $1 \alpha$ and HIF-1 $\beta$ subunits. The expression and activity of HIF-1 $\alpha$ subunit are uniquely regulated by the intracellular oxygen concentration (2). Under normoxic conditions, HIF-1 $\alpha$ protein is degraded rapidly and continuously by ubiquitination and proteasome degradation pathway. Under hypoxic conditions, HIF-1 $\alpha$ protein accumulates and translocates to the nucleus where it forms an active complex with HIF-1 $\beta$, which activates transcription of its target genes important for the adaptation and survival under hypoxia (3). Overexpression of HIF- $1 \alpha$ protein has been demonstrated in many human cancers and their metastases, and it is associated with increased vascularity, invasion and metastasis, tumor progression and treatment resistance (4). Therefore, HIF-1 $\alpha$ has been identified as an important molecular target for tumor therapy.

Oligomer procyanidins (F2) (degree of polymerization: 2-15) is a natural fraction extracted from grape seeds, the characterization and composition of which have been reported previously (5-7). We previously found that F2 could cross the blood-brain barrier, enhance the $\cdot \mathrm{OH}$ scavenging ability in rat brain and protect mouse brain against ethanol-induced oxidative DNA damage (8). Since both the overproduction of - $\mathrm{OH}$ and oxidative DNA damage occur in tumors, we further investigated the antitumor effect of $\mathrm{F} 2$ in vitro, and found that F2 could inhibit the growth of multiple cancer cells and induce U87 cells paraptosis (9). We also found that F2 could significantly inhibit the migration and invasion of fMLF (a FPR1 agonist)-induced U87 cells due to its partial agonist action on formyl peptide receptor 1 (FPR1) (10). FPR1 is a membrane receptor overexpressed in U87 cells, regulates the cell growth, survival, migration and invasion $(11,12)$. Moreover, an in vivo study showed that repeated administration of F2 to mice had no adverse effects (13). These data suggest that F2 may serve as a safe and efficient antitumor agent. However, the underlying antitumor mechanism of F2 is not clear and needs considerably more research.

Based on the evidence that HIF-1 $\alpha$ was highly expressed in human astrocytoma U251 and human hepatoma Hep3B 
cell lines and mediated their multiple tumor biology $(14,15)$, and our findings that cell viability of both cell lines could be significantly inhibited by F2 under normoxic conditions (9), we selected the U251 and Hep3B cell lines to investigate the antitumor effect of F2 targeting HIF-1 $\alpha$ to further explain its antitumor mechanism, which will help define the characteristics of F2 and may contribute to the discovery of novel antitumor or prevention agents.

\section{Materials and methods}

Preparation of F2. The grape seed (Vitis vinifera, cv. Fernão Pires) powder $(200 \mathrm{~g})$ was firstly extracted using 31 of methanol-water $(80: 20, \mathrm{v} / \mathrm{v})$, followed by 31 acetone-water $(75: 25, \mathrm{v} / \mathrm{v})$ to obtain crude phenolic extract as described previously (5). After removing the organic solvents, the crude phenolic extract was chromatographed on a Lichroprep RP-18 (200x25 mm i.d.; 25-40 m particle size; Merck, Darmstadt, Germany) column to isolate F2 with the procedures similar to those already described (6). Briefly, F2 was extracted from the grape seed methanolic extract and evaporated at $<30^{\circ} \mathrm{C}$ to dryness, and dissolved in double distilled water prior to lyophilization. The chemical and structural characterization of F2 was determined by normal-phase and reverse-phase HPLC, thioacidolysis-HPLC, ESI-MS analyses, formaldehyde- $\mathrm{HCl}$ precipitation and elemental analysis (7). The powder of F2 obtained was endotoxin free and stored at $-20^{\circ} \mathrm{C}$ until used. For cells culture work in vitro, a $10 \mathrm{mg} / \mathrm{ml}$ aqueous stock solution was prepared and sterilized using the $0.22-\mu \mathrm{m}$ filter.

Cell lines and reagents. Human astrocytoma U251 cell line (ATCC, Rockville, MD, USA), human hepatoma Hep3B cell line (ATCC) and human umbilical vein endothelial cells (HUVECs) (National Center for Medical Culture Collection, China) were routinely cultured in DMEM and/or RPMI-1640 supplemented with 10\% FBS (Gibco-BRL, Rockville, MD, USA) and maintained at $37^{\circ} \mathrm{C}$ in a humidified incubator with $5 \% \mathrm{CO}_{2}$ (referred to as normoxic conditions). U251-HRE (cells stably transfected with pGL2-TK-HRE plasmid) and U251-pGL3 (cells stably transfected with pGL3-control plasmid) cells were cultured in RPMI-1640 with 5\% FBS and $100 \mu \mathrm{g} / \mathrm{ml} \mathrm{G} 418$ (Sigma, CA, USA). For cell culture under hypoxic conditions, cells were grown in a modular incubator chamber (CA, USA) containing $1 \% \mathrm{O}_{2}, 5 \% \mathrm{CO}_{2}$ and $94 \% \mathrm{~N}_{2}$ at $37^{\circ} \mathrm{C}$. Hypoxia can also be induced using the hypoxia mimetic agent desferoxamine (Sigma).

Rapamycin, LY294002, cycloheximide (CHX), MG132 and dimethyloxalylglycine (DMOG) were purchased from Sigma. PD98059 was purchased from Beyotime (S1805, China). Recombinant human VEGF and EGF were purchased from Peprotech (Rocky Hill, NJ, USA). HIF-1 $\alpha$ siRNA and control siRNA were purchased from Santa Cruz (CA, USA). Primary antibodies against HIF- $1 \alpha$ and HIF- $1 \beta$ were purchased from BD-Transduction Laboratories (MA, USA). Antibodies specific for phosphorylated (Ser-308) or total AKT, phosphorylated (Ser-2448) or total mTOR, phosphorylated (Thr-389) or total p70S6K, phosphorylated (Ser-65) or total 4E-BP1, phosphorylated p44/42 ERK1/2 (T202/Y204) or p44/42ERK1/2 and phosphorylated (Tyr-992) or total EGFR and $\beta$-actin were purchased from Cell Signaling Technology (CA, USA).
Transient transfection and luciferase reporter assays. pGL2TK-HRE plasmid, containing three copies of the hypoxiaresponsive element from the inducible nitric oxide synthase promoter upstream of the firefly luciferase reporter gene, was kindly provided by Giovanni Melillo (National Tumor Institute, Frederick, MD, USA). Hep3B cells were transiently transfected with $0.5 \mu \mathrm{g}$ pGL2-TK-HRE plasmid. Afterward, cells were treated with different concentrations of F2 $(\mu \mathrm{g} / \mathrm{ml})$ followed by exposure to hypoxia for $16 \mathrm{~h}$. Cell lysates were collected and luciferase levels were subsequently assayed using the Bright-Glo ${ }^{\mathrm{TM}}$ luciferase assay system (Promega, WI, USA).

Western blot analysis. Western blot analysis was performed as described previously (10). In brief, equal amounts of total protein extracts from cultured cells were fractionated by $4-15 \%$ SDS-PAGE and electrically transferred onto polyvinylidene difluoride (PVDF) membranes (Millipore, Darmstadt, Germany). Mouse or rabbit primary antibodies and appropriate horseradish peroxidase (HRP)-conjugated secondary antibodies (CST, CA, USA) were used to detect the designated proteins. Membrane-bound secondary antibodies were detected with ECL reagents (Invitrogen, CA, USA) and exposed to X-ray film. Results were normalized to the internal control ( $\beta$-actin).

Real-time PCR and RT-PCR. Total RNA was isolated using RNeasy Mini kit (Qiagen, Germany) following the manufacturer's instructions. RNA $(1 \mu \mathrm{g})$ was reverse transcribed with a RevertAid First Strand cDNA Sythesis kit (Toyobo, Japan). For quantitative PCR, analysis was carried out using iQ SYBR Green Supermix (Bio-Rad, CA, USA) and a CFX96 RealTime PCR Detection System (Bio-Rad) as instructed by the manufacturer. RT-PCR reactions were performed as described previously (8).

Quantitation of VEGF production. Cells were incubated in the 6-well culture plates (Corning Costar, NY, USA) and treated with $\mathrm{F} 2(\mu \mathrm{g} / \mathrm{ml})$ under normoxic and hypoxic conditions for $16 \mathrm{~h}$. Cells culture medium were collected and centrifuged at $800 \mathrm{rpm}$ for $5 \mathrm{~min}$ at $4^{\circ} \mathrm{C}$ to remove cellular debris. VEGF in the medium was measured by using the Quantikine human VEGF ELISA kit (R\&D Systems, MN, USA) according to the manufacturer's instructions.

Cell invasion assay. Cells $\left(10-20 \times 10^{4}\right)$ were plated in cell basal medium in the upper chamber of a Transwell $(8 \mu \mathrm{m}$, Corning Costar), pre-coated with matrigel (BD, MA, USA). Serum-free RPMI-1640 medium with or without of F2 $(\mu \mathrm{g} / \mathrm{ml})$ was added to the upper and lower chamber of the Transwell. After 12 or $16 \mathrm{~h}$, non-migrated cells were removed with cotton swab and migrated cells were stained and examined using ImageXpress Micro XLS Widefield High Content Screening System (Molecular Devices, CA, USA), the number of migrated cells was quantified by counting the cell number.

Tube formation assay. Matrigel (50 $\mu \mathrm{l})$ mixed with serum-free RPMI-1640 medium (1:1) were placed into each well of the 96-well-plate (Corning Costar) and allowed to polymerize by 
A

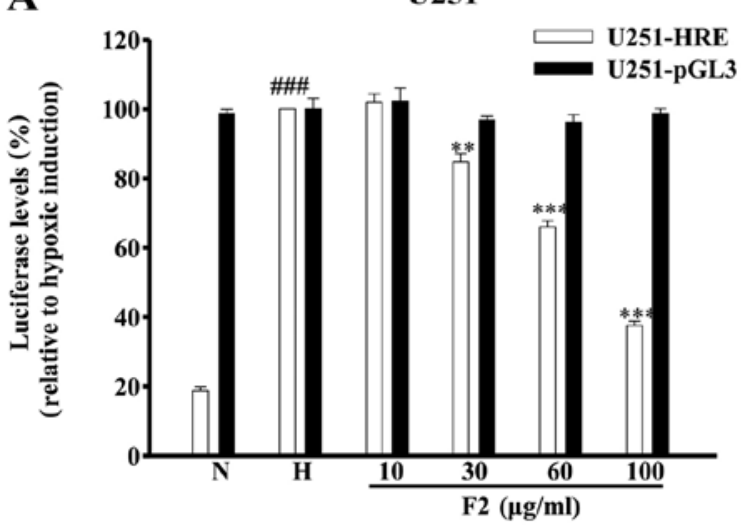

B



C

U251

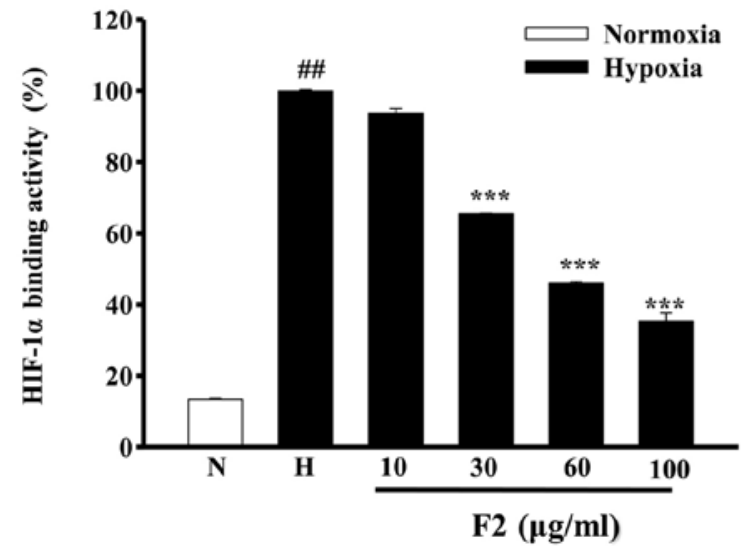

Hep3B

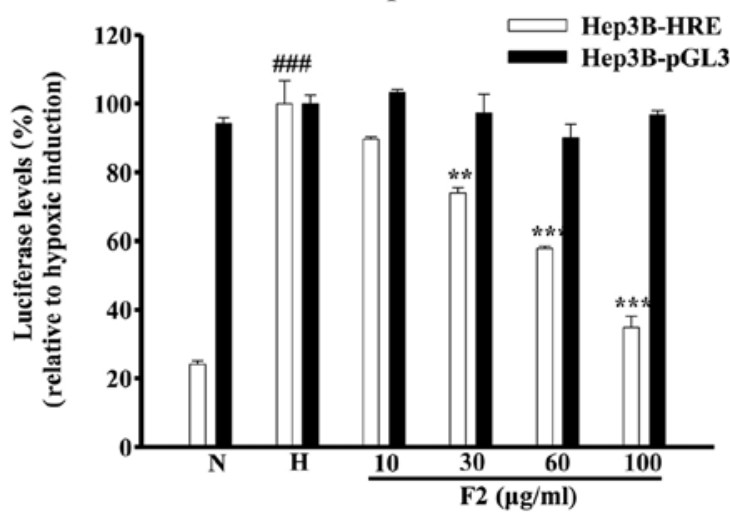

Hep3B

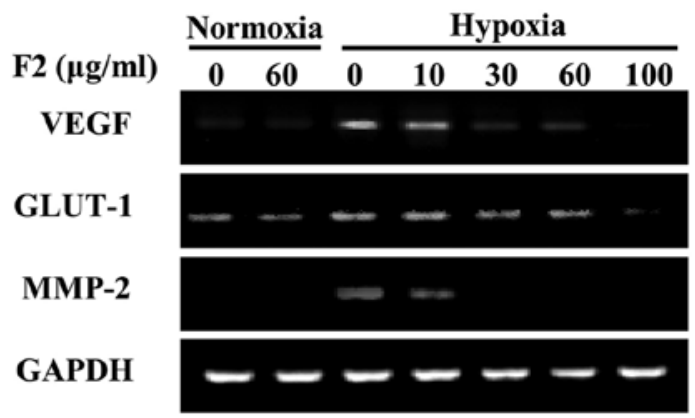

Hep3B

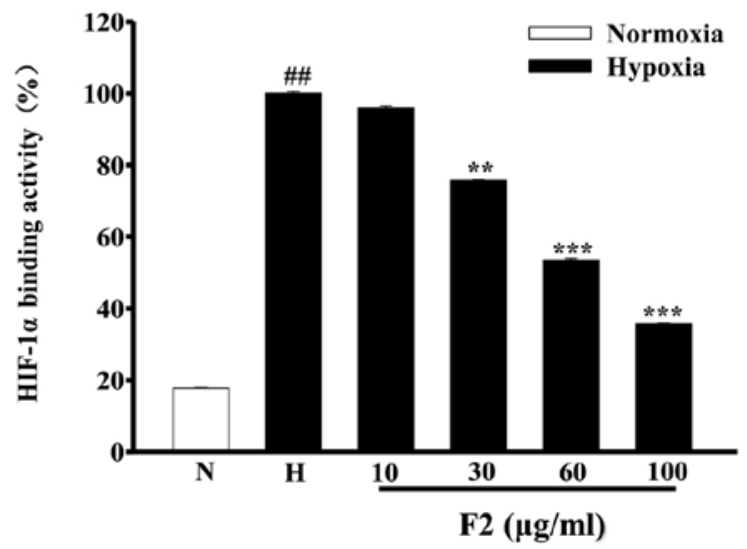

Figure 1. F2 inhibits HIF-1 activity and its target gene mRNA expression. (A) Cells treated with different concentrations of F2 ( $\mu \mathrm{g} / \mathrm{ml}$ ) for $16 \mathrm{~h}$ were tested for luciferase levels. Values are means $\pm \mathrm{SE}$ of three independent experiments performed in triplicate. ${ }^{* *} \mathrm{P}<0.01 ;{ }^{* * * *} \mathrm{P}<0.001 ;$ significant difference in normoxia $(\mathrm{N})$


concentrations of $\mathrm{F} 2(\mu \mathrm{g} / \mathrm{ml})$ for $8 \mathrm{~h}$. The results are representative of three independent experiments. (C) Cell nucleus proteins of cells treated with different concentrations of F2 $(\mu \mathrm{g} / \mathrm{ml})$ for $8 \mathrm{~h}$ were extracted for HIF-1 $\alpha$ binding activity assay. Values are means \pm SE of three independent experiments performed in triplicate, ${ }^{* *} \mathrm{P}<0.01 ;{ }^{* * *} \mathrm{P}<0.001$; significant difference in normoxia $(\mathrm{N})$ vs. hypoxia $(\mathrm{H})$ group, ${ }^{\#, \# \#} \mathrm{P}<0.01$.

incubation at $37^{\circ} \mathrm{C}$ for $30 \mathrm{~min}$. A mixture of HUVECs $\left(5 \times 10^{4} \%\right.$ well) $(100 \mu \mathrm{l})$ was seeded on the gel with or without culture medium (CM) (100\%), then incubated at $37^{\circ} \mathrm{C}$ for $12 \mathrm{~h}$. Cells were stained and examined, and tube formation (branches/ field) was examined and quantified.

Statistical analysis. Results are expressed as means \pm SE of three independent experiments done in triplicate. One-way ANOVA followed by Dunnett's t- and T3-test were used for statistical analysis (SPSS 16.0 software, SPSS, USA).

\section{Results}

F2 inhibits HIF-1a expression in U251 and Hep3B cells. We used U251-HRE and U251-pGL3 cells (HIF-1 $\alpha$ inhibitor screening model) to detect whether F2 inhibited the HIF-1 $\alpha$ activity (16). As shown in Fig. 1A, the hypoxia-induced luciferase expression in U251-HRE cells, but not the constitutive luciferase in U251-pGL3 control cells, was significantly decreased by $\mathrm{F} 2$ in a concentration-dependent manner $(\mathrm{P}<0.01)$. Similar results were obtained in Hep3B-HRE and 
$\mathbf{A}$

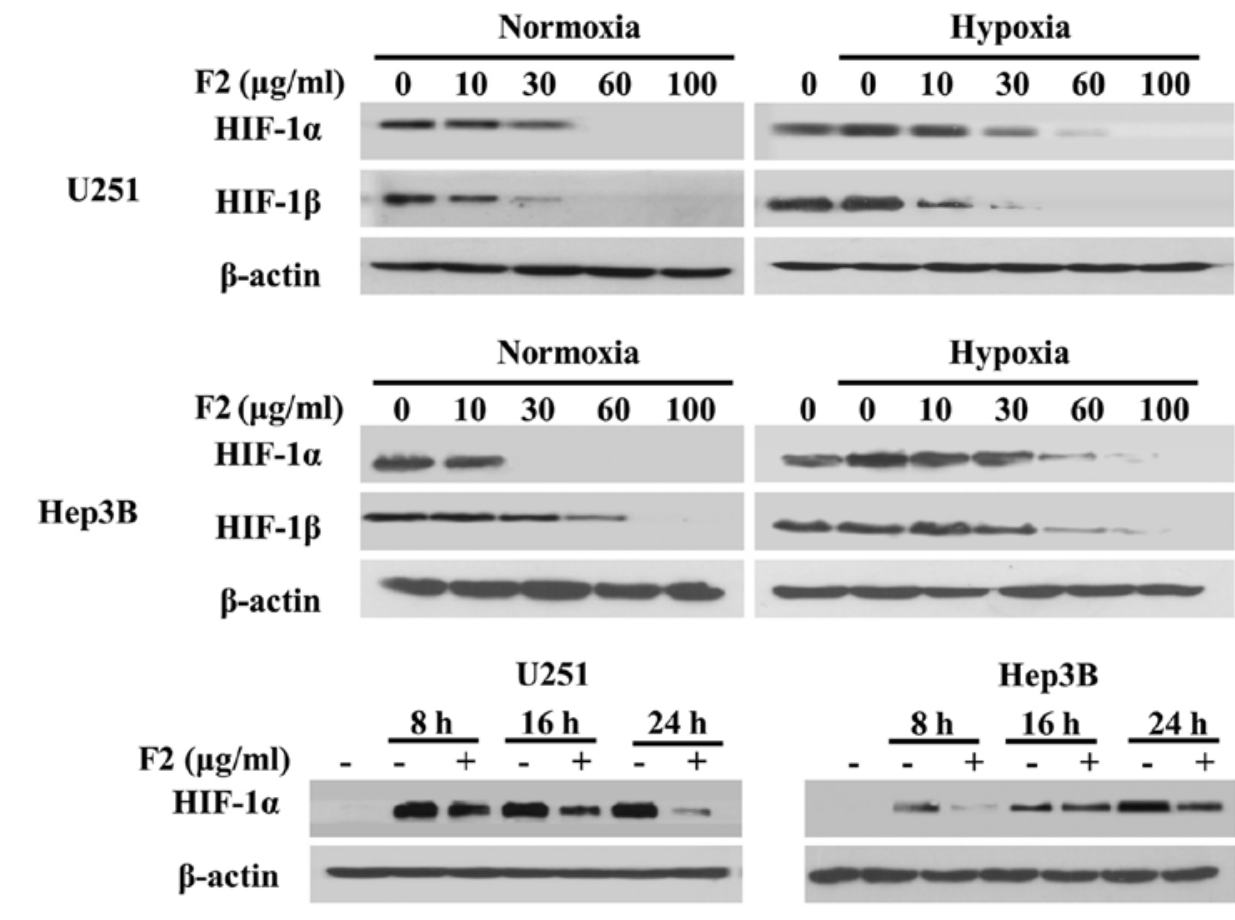



$\mathbf{E}$

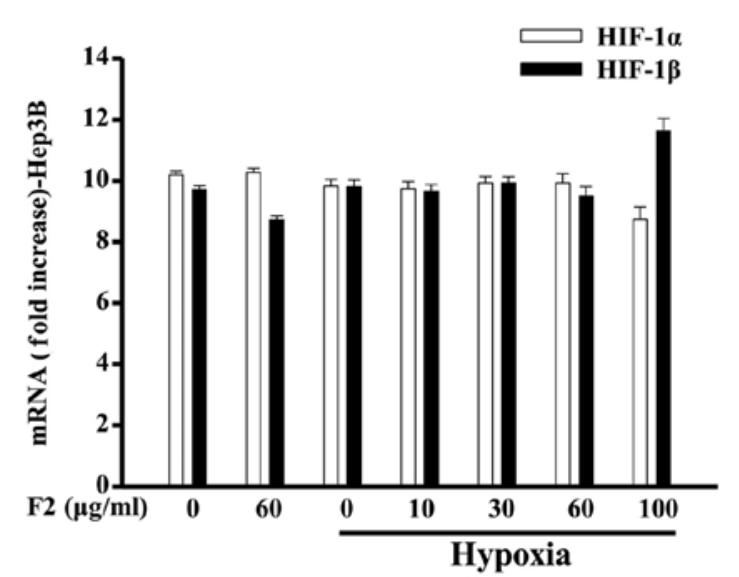

Hep3B
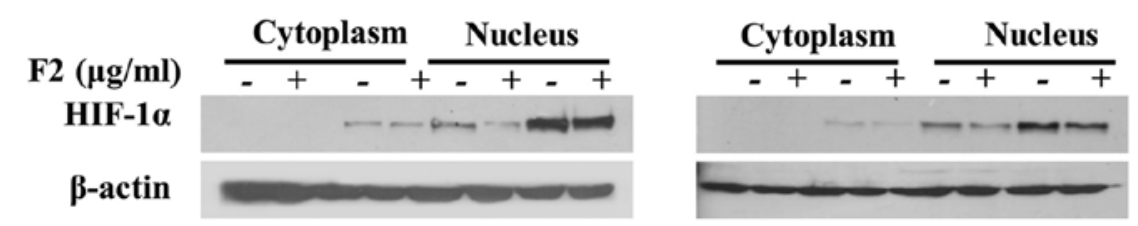

Figure 2. F2 decreases the expression of HIF-1 $\alpha$ and HIF-1 $\beta$ protein in U251 and Hep3B cells. (A-C) Western blot analysis of total proteins of cells treated with different concentrations of $\mathrm{F} 2(\mu \mathrm{g} / \mathrm{ml})$ for relative time-point (h). (D) Cells were treated with different concentrations of F2 ( $\mu \mathrm{g} / \mathrm{ml})$ for $8 \mathrm{~h}$, total RNA was extracted for real-time PCR. The diagram shows relative amounts of mRNA levels in F2 treated vs. normoxic or hypoxic group. Values are means \pm SE of three independent experiments performed in triplicate. (E) Cytoplasm and nucleus proteins of cells treated with F2 (60 $\mu \mathrm{g} / \mathrm{ml})$ for $8 \mathrm{~h}$ were extracted using a kit (Thermo Scientific) for western blot analysis.

Hep3B-pGL3 transiently transfected cells $(\mathrm{P}<0.01)$. The effects of F2 on the expression of HIF-1 target genes mRNA were examined. As shown in Fig. 1B, hypoxic induction of VEGF, GLUT-1 and MMP-2 mRNA were markedly blocked by F2 in a concentration-dependent manner. In addition, HIF-1 $\alpha$ DNA binding activity in both cell lines was also significantly decreased in the presence of F2 ( $\mathrm{P}<0.01$, Fig. 1C).

In order to evaluate how F2 inhibits HIF-1 $\alpha$ activity, HIF-1 $\alpha$ and HIF-1 $\beta$ in both cells were investigated at protein and mRNA levels by western blot analysis and real-time PCR, respectively. As shown in Fig. 2A-C, F2 inhibited the expressions of HIF-1 $\alpha$ and HIF-1 $\beta$ protein in both cells under normoxic and hypoxic conditions in a concentration- and/or time-dependent manner without obvious changes in the cell viability ( $\mathrm{P}>0.05$, data not shown). For the concentrationdependent inhibition of HIF-1 $\alpha$ protein levels, no significant difference between U251 and Hep3B cells was observed. In addition, F2 also exerted a concentration-dependent inhibition 
A

U251

\section{Hep3B}
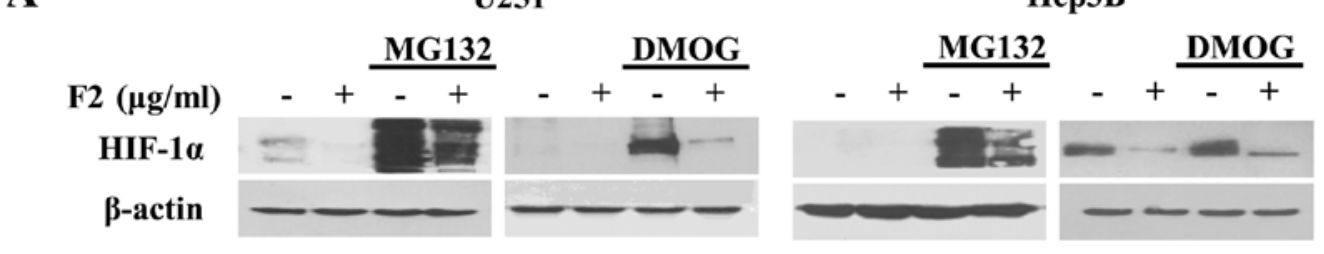

B

$\mathbf{U} 251$
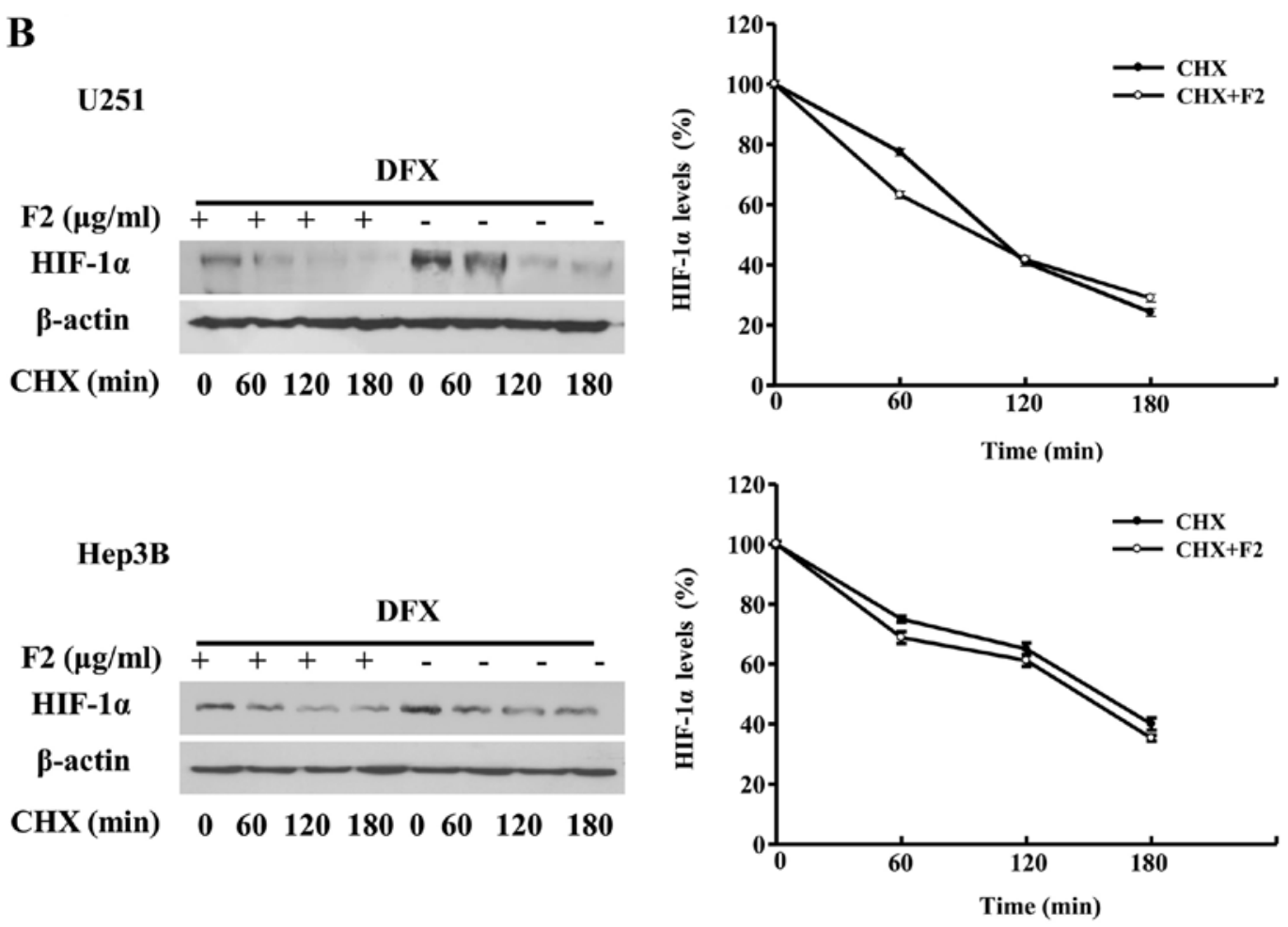

C

U251

Hep3B


Figure 3. F2 does not destabilize the HIF-1 $\alpha$ in U251 and Hep3B cells. (A) Cells were treated with MG132 (20 $\mu \mathrm{M})$ or DMOG (100 $\mu \mathrm{M})$ for $8 \mathrm{~h}$ under normoxic conditions in the presence and absence of $\mathrm{F} 2(60 \mu \mathrm{g} / \mathrm{ml})$, cell lysates were then collected for western blot analysis to determine HIF-1 $\alpha$. (B) Cells were treated with DFX $(100 \mu \mathrm{M})$ in the presence or absence of F2 $(60 \mu \mathrm{g} / \mathrm{ml})$ for $2 \mathrm{~h}$, and then CHX $(40 \mu \mathrm{g} / \mathrm{ml})$ was added for the indicated time. Values were normalized to $\beta$-actin and expressed as a percentage relative to time 0 , considered equal to $100 \%$. (C) Total proteins of cells treated with different concentrations of $\mathrm{F} 2(\mu \mathrm{g} /$ $\mathrm{ml}$ ) for $16 \mathrm{~h}$ were collected for western blot analysis.

of hypoxic-induced accumulation of HIF-1 $\alpha$ protein in other cell lines, such as A549 and MDA-MB-435S cell lines (data not shown).

For the HIF- $1 \alpha$ and HIF-1 $\beta$ mRNA, no appreciable effects of F2 were found in either cell line, leaving a random distribution and an inconsistent pattern (P>0.05, Fig. 2D). Since HIF-1 activity is primarily determined by HIF-1 $\alpha$ subunit in the nucleus, we also determined the presence of HIF-1 $\alpha$ in the nucleus and cytoplasm, and found that the nuclear translocation of HIF-1 $\alpha$ in both cell lines were not changed in the presence of F2 (Fig. 2E) under normoxic or hypoxic conditions.

$F 2$ does not affect the degradation or stability of HIF-1 $\alpha$. In order to test whether the inhibitory effect of F2 on HIF-1 $\alpha$ protein expression was associated with the degradation induction of HIF-1 $\alpha$ via the prolyl-hydroxyltion-proteasome pathway, we assessed the impact of F2 on HIF-1 $\alpha$ protein degradation in the presence of MG132 (a proteasome inhibitor) and DMOG (a prolyl hydroxylase inhibitor) (17). As shown in Fig. 3A, the MG132 $(20 \mu \mathrm{M})$ and DMOG $(100 \mu \mathrm{M})$-induced increase in expression of HIF- $1 \alpha$ was decreased by F2 $(60 \mu \mathrm{g} /$ $\mathrm{ml})$ under normoxic condition. Immuno-fluorescence assay showed that F2 also downregulated the expression level of hydroxylation-HIF-1 $\alpha$ (hy-HIF-1 $\alpha$ ) induced by MG132 in Hep3B cells (data not shown). In this study, HIF-1 $\alpha$ protein was expressed as two bands and slightly dispersed in cells treated with MG132 due to its poly-ubiquitylation modification, which was consistent with previous results (18). These 
A

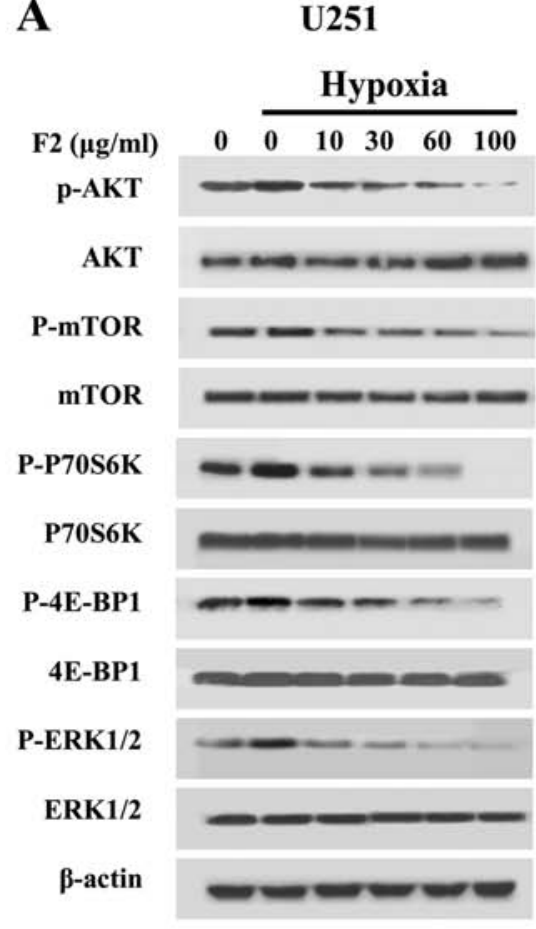

Нер3В
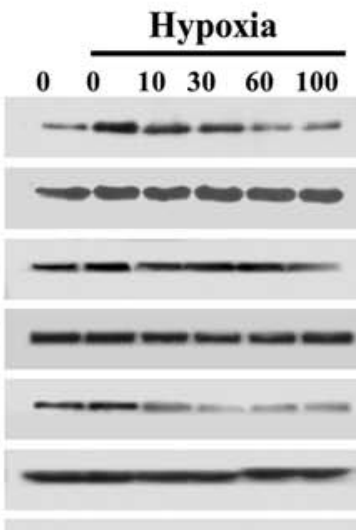

20. -



B

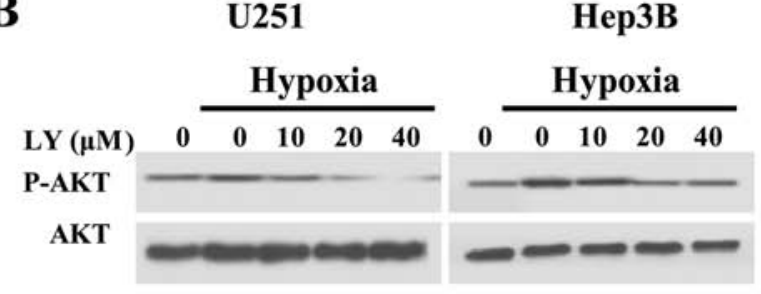



P-ERK1/2

ERK1/2

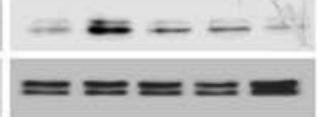

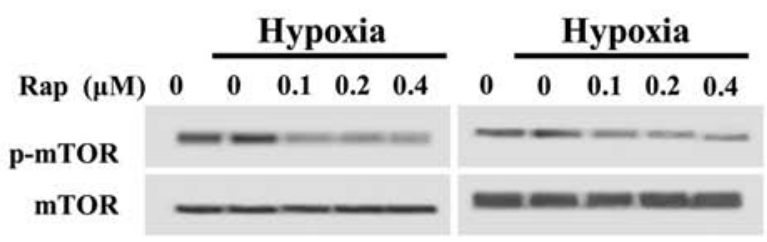

C



Figure 4. F2 inactivates the PI3K-AKT-mTOR and MAPK-ERK1/2 pathways. (A and B) Western blot analysis of cell total proteins of cells treated with different concentrations of F2 ( $\mu \mathrm{g} / \mathrm{ml})$, LY (LY294002, $\mu \mathrm{M}$ ), Rap (rapamycin, nM), PD (PD98059, $\mu \mathrm{M}$ ) for $1 \mathrm{~h}$. (C) Western blot analysis of cell total proteins of cells treated with $\mathrm{LY}(\mu \mathrm{M}), \mathrm{PD}(\mu \mathrm{M})$, Rap (nM) for $16 \mathrm{~h}$.

results indicate that F2 suppresses the accumulation of HIF-1 $\alpha$ through a pathway independent of hydroxylation-proteasome degradation.

These results were compatible with the possibility that F2 affected the half-life of HIF- $1 \alpha$ protein and promoted its degradation through a different pathway (17). To investigate this hypothesis, experiments were performed using cycloheximide (CHX) which could inhibit de novo protein synthesis. HIF-1 $\alpha$ protein was measured before (time 0 ) and at different times after CHX was added, however, as shown in Fig. 3B, there was no change in HIF-1 $\alpha$ half-life in U251 or Hep3B cells $(\mathrm{P}>0.05)$ after treatment with $\mathrm{F} 2(60 \mu \mathrm{g} / \mathrm{ml})$.

A study also exists revealing that p53 might negatively regulate HIF-1 $\alpha$ stability by interacting directly or indirectly by targeting it for HDM2-mediated degradation (19). Therefore, the effect of F2 on p53 expression was tested to see whether F2 affected the expression of HIF-1 $\alpha$ with p53 involved. It is reported that $\mathrm{U} 251$ and Hep3B cells express mutant-p53 and deleted-p53, respectively $(20,21)$. As shown in Fig. 3C, U251 cells expressed $\mathrm{p} 53$, which was accordance with a previous report that U251 cells expressed mutant-p53 (20), while the level of p53 was decreased in the presence of F2; p53 was not detected in Hep3B cells, which might be due to the Hep3B cells expressing the deleted p53 (21). F2 also inhibited HIF-1 $\alpha$ expression in A549 cells which expressed wild-p53. It therefore seems that p53 is uninvolved in the regulation of HIF-1 $\alpha$ expression by F2, because HIF-1 $\alpha$ expressions were inhibited by $\mathrm{F} 2$ regardless of the type of $\mathrm{p} 53$ in cells or whether $\mathrm{p} 53$ existed or not.

Taken together, these data indicate that F2 does not influence the degradation or stability of HIF-1 $\alpha$, raising the possibility that it may affect its translation.

F2 inactivates hypoxia-induced PI3K-AKT-mTOR and $M A P K-E R K 1 / 2$ pathways. We next investigated whether F2 affected the expression of HIF-1 $\alpha$ through the PI3K-AKTmTOR and ERK1/2 pathways, by inhibiting the HIF-1 $\alpha$ translational regulators P70S6K and 4E-BP1 (22-24). As shown in Fig. 4A, hypoxic induction of the p-AKT, p-mTOR, p-P70S6K, p-4E-BP1 and p-ERK1/2 in both cell lines were 
A

U251

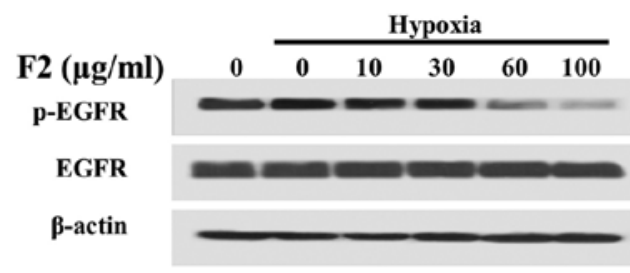

B

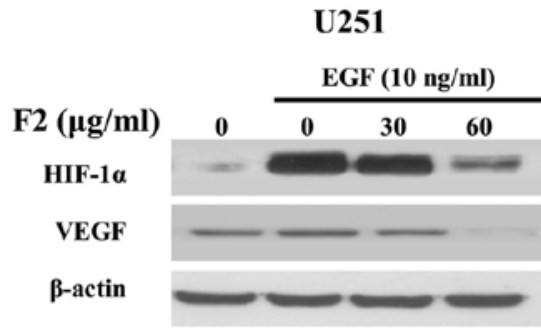

C

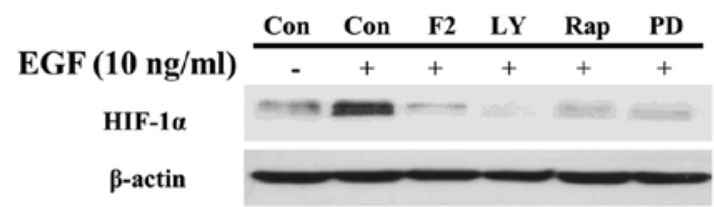

D

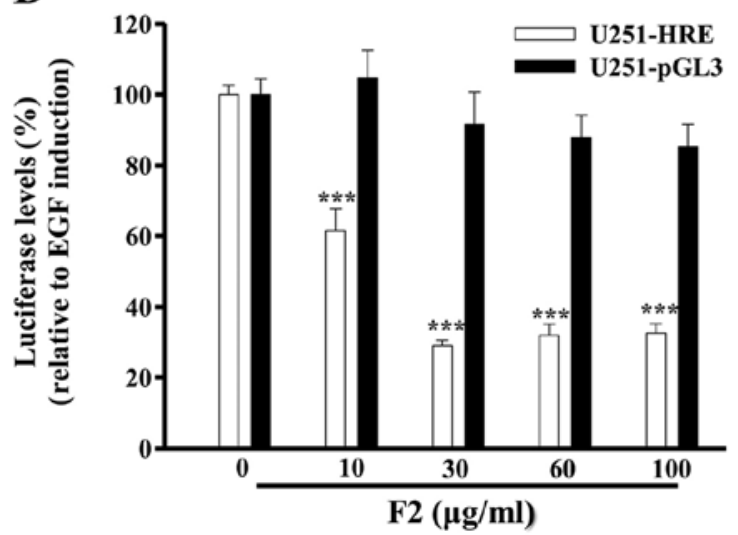

Hep3B



\section{Нер3B}

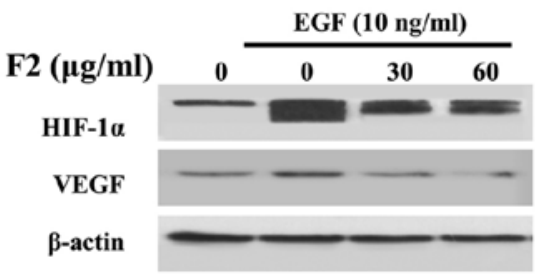

Hep3B
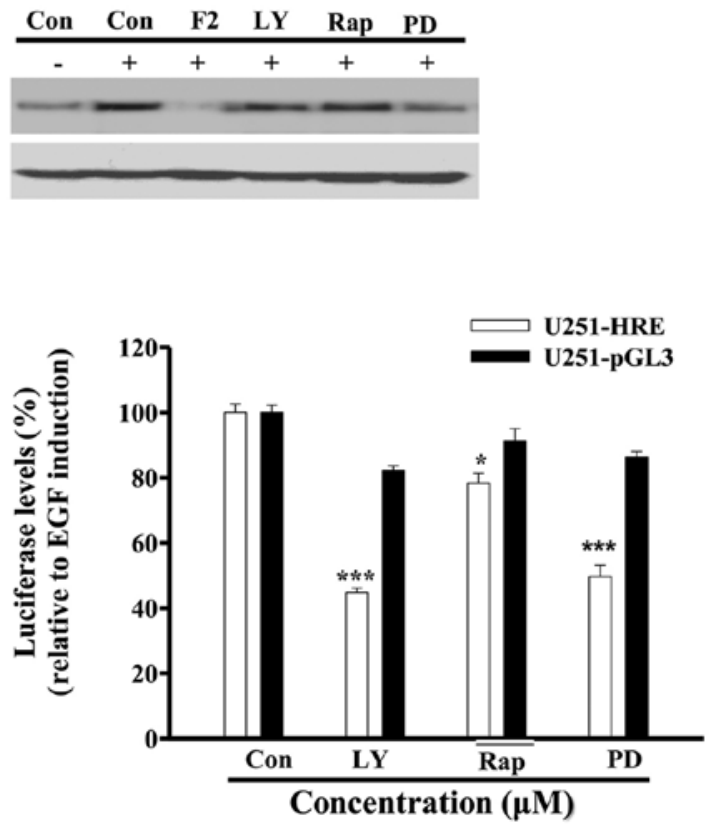

Figure 5. F2 inhibits the activation of EGFR pathway in U251 and Hep3B cells. (A) Western blot analysis of total proteins of cells treated with different concentrations of $\mathrm{F} 2(\mu \mathrm{g} / \mathrm{ml})$ for $1 \mathrm{~h}$. (B and C) Cells were starved for $24 \mathrm{~h}$, then treated with F2 $(\mu \mathrm{g} / \mathrm{ml}), \mathrm{LY}(20 \mu \mathrm{M}), \operatorname{Rap}(400 \mathrm{nM})$, PD $(50 \mu \mathrm{M})$ in the presence or absence of EGF $(10 \mathrm{ng} / \mathrm{ml})$ for $16 \mathrm{~h}$, cell total proteins were collected for western blot analysis. (D) U251-HRE cells were starved for $24 \mathrm{~h}$, then treated with different concentrations of $\mathrm{F} 2(\mu \mathrm{g} / \mathrm{ml}), \mathrm{LY}(20 \mu \mathrm{M})$, Rap $(400 \mathrm{nM}), \mathrm{PD}(50 \mu \mathrm{M})$ in the presence or absence of EGF $(10 \mathrm{ng} / \mathrm{ml})$ for $16 \mathrm{~h}$. Luciferase levels were tested using Bio-Glo bright luciferase reagent. The diagram shows relative amounts of luciferase levels in the treated group vs. EGF group. Values are means $\pm \mathrm{SE}$ of three independent experiments performed in triplicate, ${ }^{*} \mathrm{P}<0.05 ;{ }^{* * *} \mathrm{P}<0.001$.

decreased by F2 in a concentration-dependent manner. In addition, LY294002 (PI3K inhibitor), rapamycin (mTOR inhibitor) and PD98059 (MEK1 inhibitor) could inhibited the p-AKT, p-mTOR and p-ERK1/2 induced by hypoxia followed by downregulation of the level of HIF-1 $\alpha$ (Fig. 4B and C). These results indicate that the inhibitory effect of F2 on HIF-1 $\alpha$ protein expression is associated with the inactivation of PI3K-AKT-mTOR and MAPK-ERK1/2 pathways.

F2 inhibits the activation of EGFR signaling pathway. Epidermal growth factor receptor (EGFR) is overexpressed and activated in a variety of tumors, and has been reported to regulate the translation and expression of HIF-1 $\alpha$ through the PI3K-AKT-mTOR and MAPK-ERK1/2 pathways $(25,26)$. In this study, we found that hypoxia promoted the phosphorylation of EGFR (p-EGFR) in both U251 and Hep3B cells, and this could be abrogated in the presence of F2 (Fig. 5A). As a ligand of EGFR and one target gene of HIF-1, EGF $(10 \mathrm{ng} / \mathrm{ml})$ also could dramatically induce the expression of HIF-1 $\alpha$ and VEGF, both of which were decreased by F2 in a concentration-dependent manner (Fig. 5B). In addition, EGF induction of HIF-1 $\alpha$ protein and luciferase levels $(\mathrm{P}<0.05)$ were both inhibited by LY294002, rapamycin and PD98059 $(\mathrm{P}<0.05$, Fig. 5C and D). These results are consistent with the previous 
A
U25
Hep3B

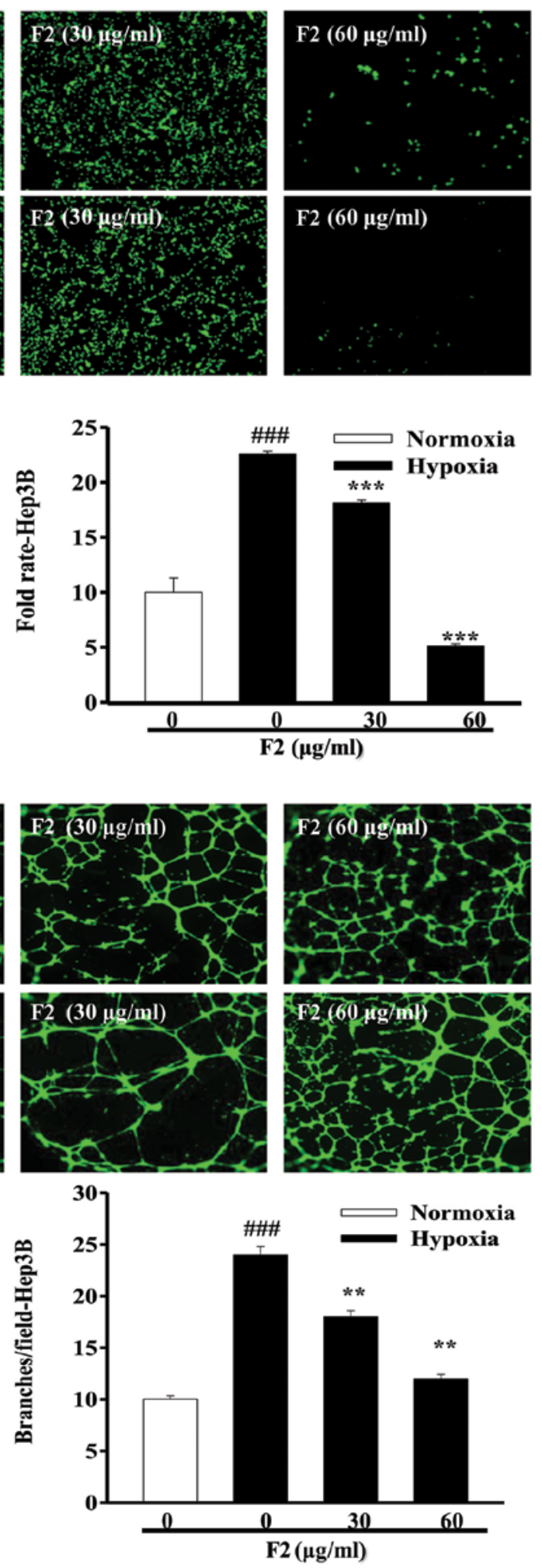

Figure 6. F2 inhibits HUVEC invasion and tube formation in vitro. (A and B) U251 and Hep3B cells were treated with different concentrations of F2 ( $\mu$ g/ml) for $16 \mathrm{~h}$ under normoxic and hypoxic conditions, culture medium $(\mathrm{CM})$ was collected for HUVEC invasion and tube formation assay. Values are means \pm SE



report and confirm that EGFR acts as an upstream mediator of HIF-1 $\alpha$ in both cell lines, and probably is a potential target of $\mathrm{F} 2$.

F2 inhibits tumor angiogenesis in vitro. The results above showed that F2 could inhibit the expression levels of HIF-1 $\alpha$ and its target gene-VEGF mRNA. Given the key roles of VEGF and HIF- $1 \alpha$ in the regulation of tumor angiogenesis $(27,28)$, we investigated the effect of F2 on tumor angiogenesis using the tube formation assay and HUVECs invasion assay. As shown in Fig. 6A, conditioned media (CM) collected from both cell types exposed to hypoxia were all able to promote 
A
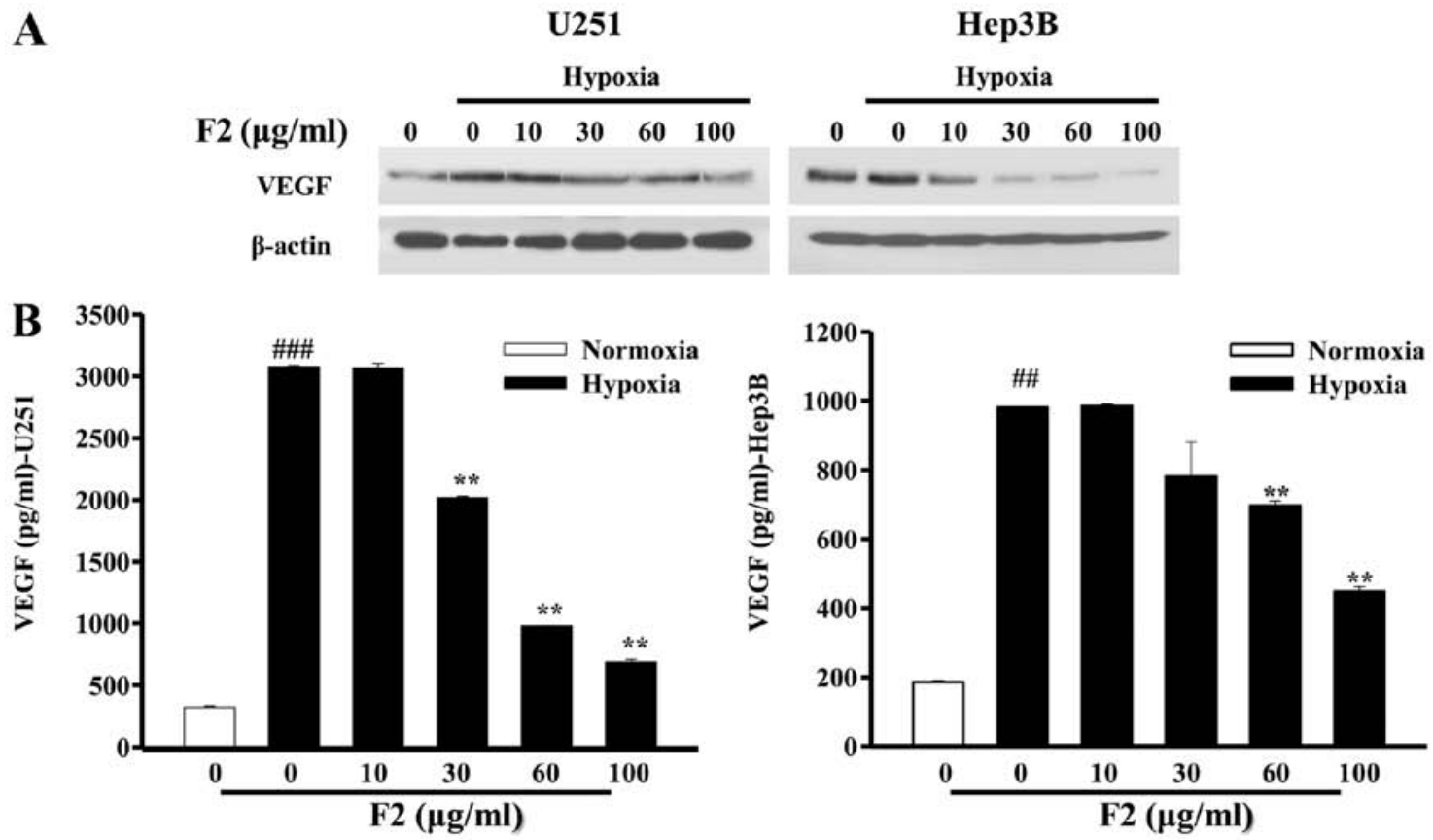

C

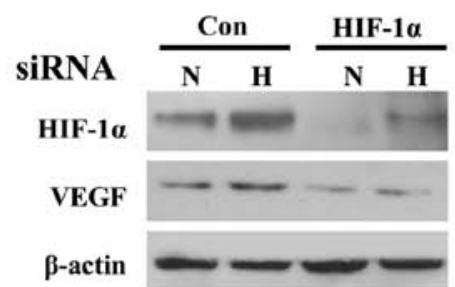

D
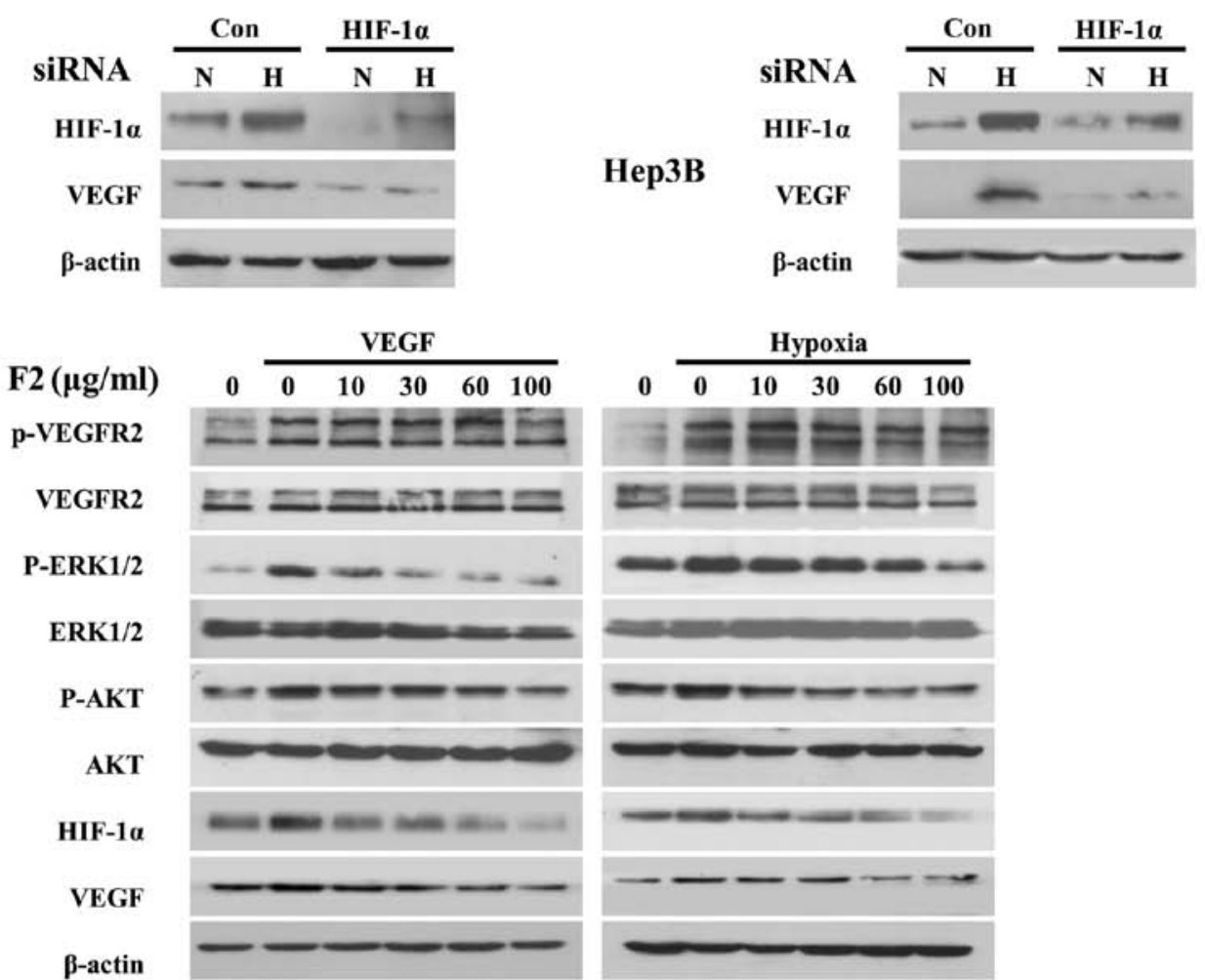

Figure 7. F2 inhibits hypoxia-induced expression of VEGF and the activation of VEGFR2/HIF-1 pathway. (A and B) The VEGF levels in culture medium and cells treated with different concentrations of $\mathrm{F} 2(\mu \mathrm{g} / \mathrm{ml})$ for $16 \mathrm{~h}$ were analyzed by ELISA and WB. Values are means \pm SE of three independent experiments performed in triplicate, ${ }^{* *} \mathrm{P}<0.01$; significant difference in normoxia vs. hypoxia group, ${ }^{\#, \# \#} \mathrm{P}<0.01 ;{ }^{\# \# \#} \mathrm{P}<0.001$. (C) Cells transfected with HIF-1 $\alpha$ siRNA and control siRNA for $24 \mathrm{~h}$ were incubated under normoxic and hypoxic conditions for $16 \mathrm{~h}$. Cell lysates were collected for western blot analysis. (D) HUVECs pre-treated with different concentrations of $\mathrm{F} 2(\mu \mathrm{g} / \mathrm{ml})$ for 30 min were incubated with VEGF $(10 \mathrm{ng} / \mathrm{ml})$ or under hypoxic conditions for $1 \mathrm{~h}$. Cell lysates were collected for western blot analysis using antibodies as indicated.

the invasion of HUVECs $(\mathrm{P}<0.001)$, whereas $\mathrm{CM}$ collected from cells exposed to hypoxia in the presence of $\mathrm{F} 2$ decreased the invasion ability of HUVECs $(\mathrm{P}<0.01)$. A similar result was obtained in the tube formation assay (Fig. 6B). Moreover, the levels of cellular and secreted VEGF proteins induced by hypoxia in both cell types were significantly inhibited by F2 in a concentration-dependent manner ( $\mathrm{P}<0.01$, Fig. $7 \mathrm{~A}$ and $\mathrm{B})$. To further confirm that VEGF level is controlled by HIF-1 $\alpha$ in both U251 and Hep3B cells, we examined whether RNA interference of HIF-1 $\alpha$ was able to knock down the protein level of VEGF. As shown in Fig. 7C, when HIF-1 $\alpha$ expression was knocked down, the levels of HIF-1 $\alpha$ and VEGF were 
A

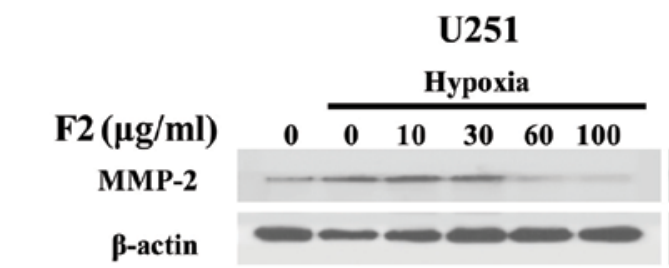

B

U251
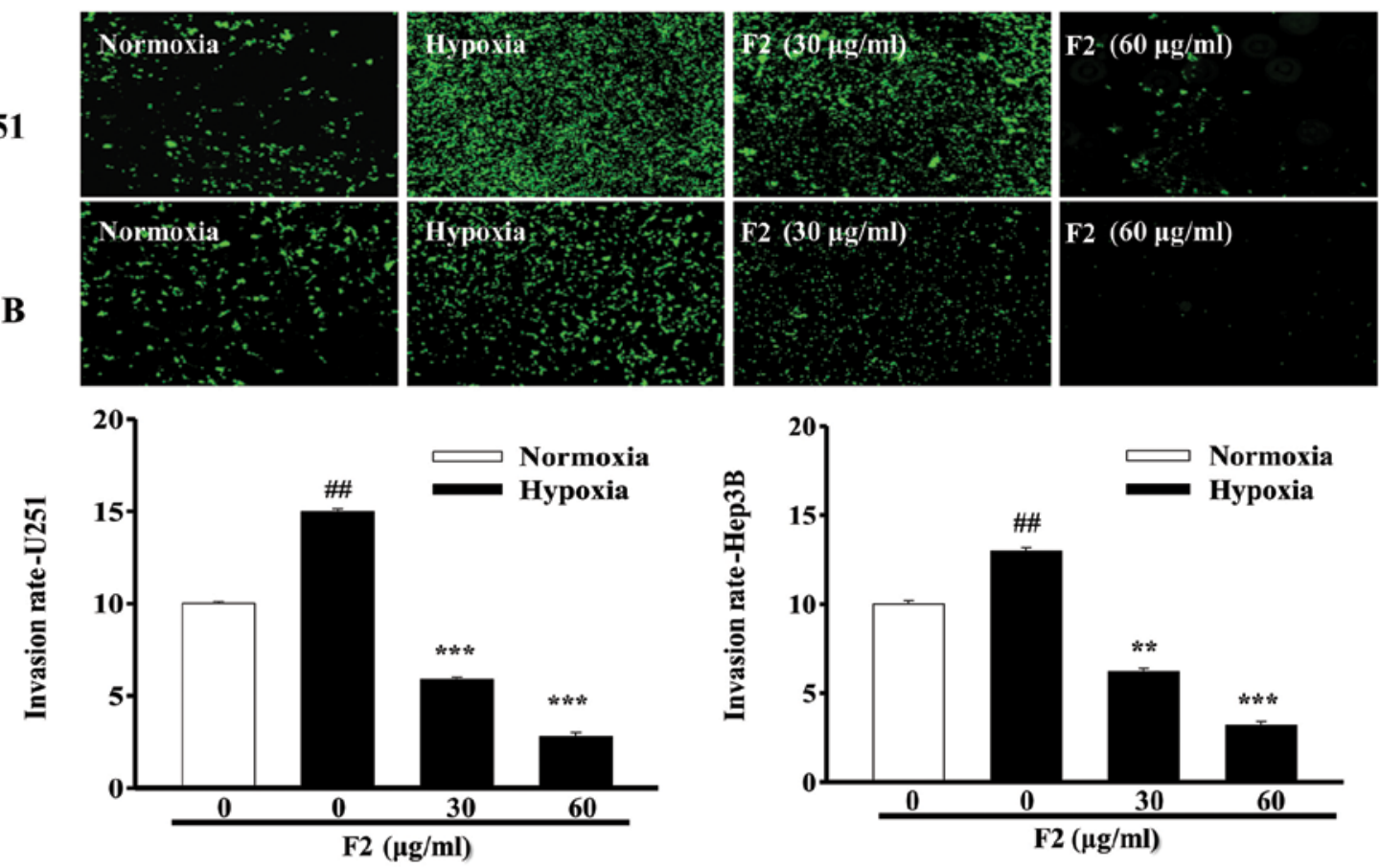

$\mathbf{C}$
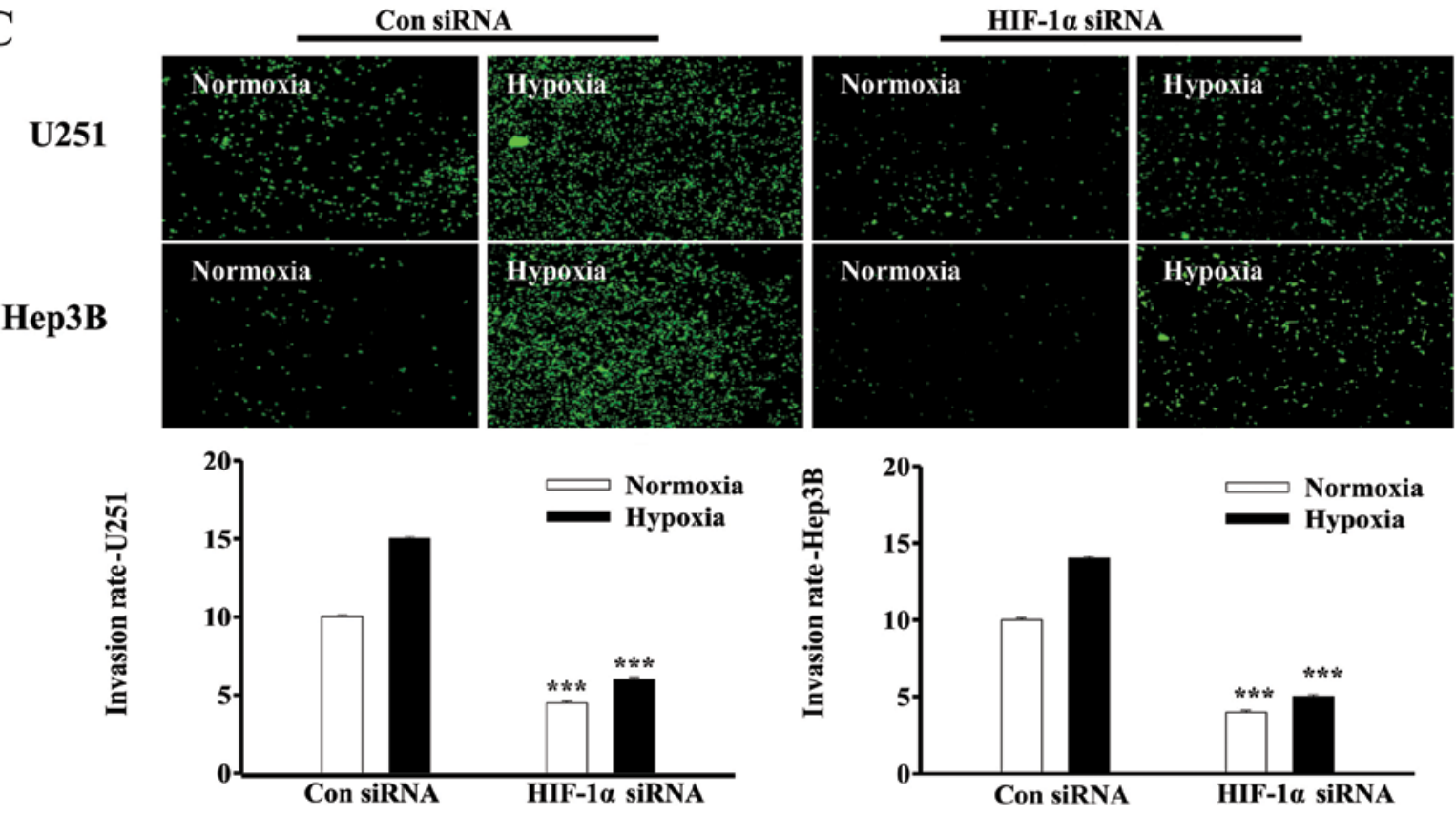

Figure 8. F2 suppresses hypoxia-induced cell invasion in vitro. (A) Total proteins of cells treated with different concentrations of $\mathrm{F} 2(\mu \mathrm{g} / \mathrm{ml})$ for $16 \mathrm{~h}$ were collected for western blot analysis. (B and C) Cells transfected with or without HIF-1 $\alpha$ siRNA and control siRNA were used for the invasion assay. Values are means \pm SE of three independent experiments performed in triplicate, ${ }^{* * *} \mathrm{P}<0.01 ;{ }^{* * * *} \mathrm{P}<0.001$; significant difference in normoxia vs. hypoxia group, ${ }^{\#, \# \#} \mathrm{P}<0.01$.

lower under normoxic conditions and unable to be upregulated by hypoxia, confirming that HIF-1 $\alpha$ is an upstream mediator of VEGF in U251 and Hep3B cells.

In addition, hypoxia also regulates the function of endothelial cells through the VEGFR2/HIF-1 pathway, which is also a classical pathway for endothelial angiogenesis $(29,30)$. As shown in Fig. 7D, p-VEGFR2, p-AKT and p-ERK1/2 induced by hypoxia or VEGF $(10 \mathrm{ng} / \mathrm{ml})$ were all decreased in the presence of F2 in HUVECs. Surprisingly, HIF-1 $\alpha$ and VEGF were also inhibited by F2 at the same time (Fig. 7D), suggesting that 


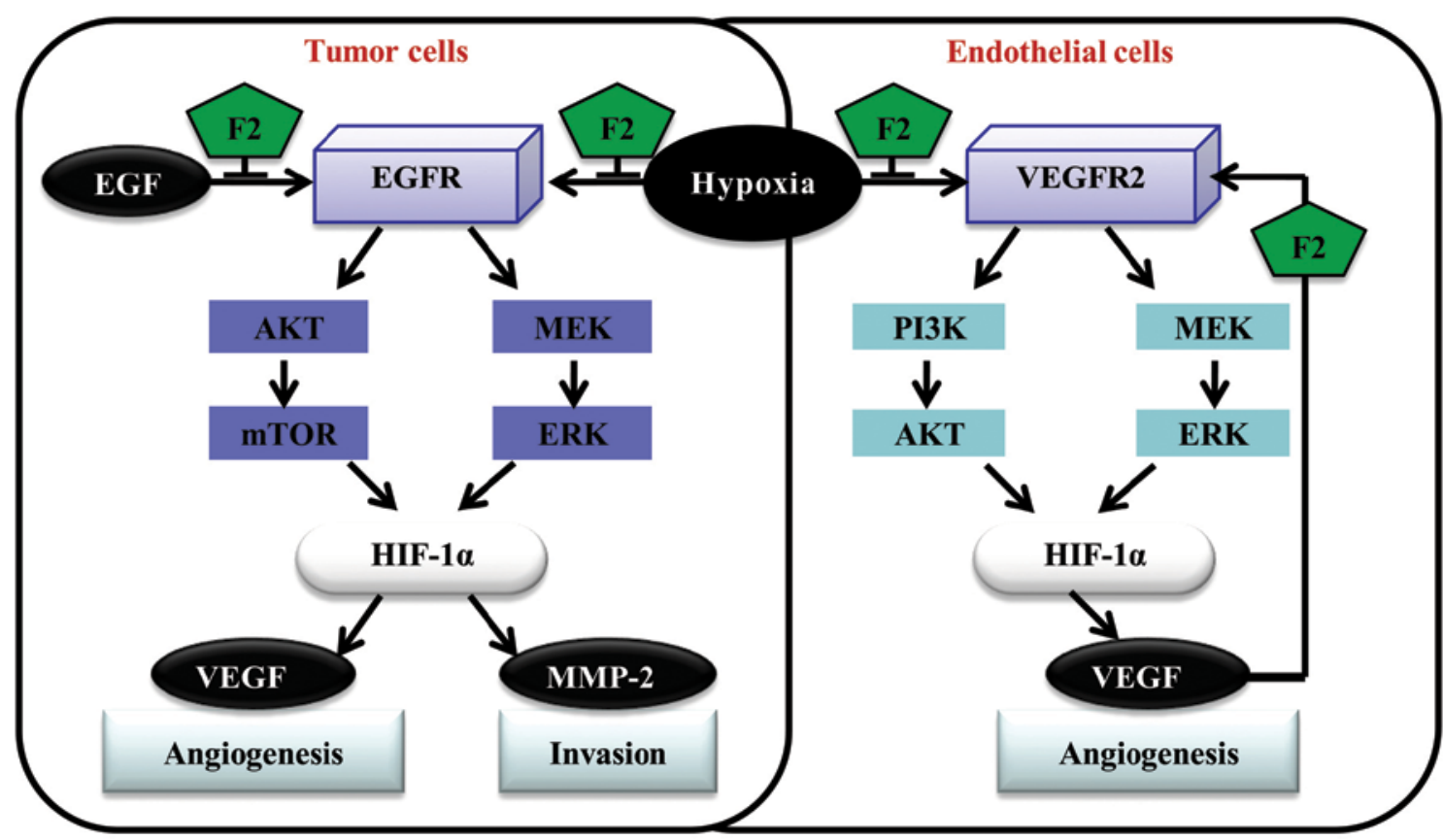

Figure 9. Schematic representation of the mechanism by which F2 inhibits HIF-1 $\alpha$ expression and has anti-angiogenesis and invasion inhibitory effects.

F2 disturbs the HIF-1/VEGF pathway not only in tumor cells, but also in endothelial cells. These results suggest that F2 may be a potential anti-angiogenesis candidate which could inhibit tumor angiogenesis by targeting the HIF-1/VEGF pathway.

F2 inhibits tumor cell invasion in vitro. Hypoxia also stimulates the invasion and migration of tumor cell through activating the HIF-1 target genes, such as MMP-2 (31). In this study, both MMP-2 mRNA and protein induced by hypoxia were decreased in the presence of F2 (Figs. $1 \mathrm{~B}$ and $8 \mathrm{~A}$ ), indicating that F2 may influence the tumor cell invasion by regulating HIF-1 $\alpha$ expression. As shown in Fig. 8B, Transwell assay results showed that hypoxia significantly induced the invasion of $\mathrm{U} 251$ and Hep3B cells $(\mathrm{P}<0.01)$, which could be reversed by F2 $(\mathrm{P}<0.01)$. To further confirm that hypoxia-induced cell invasion was mediated by HIF- $1 \alpha$, HIF- $1 \alpha$ siRNA was used to knock down the HIF-1 $\alpha$ expression in both cell types. Invasion of both types of tumor cells were impaired under normoxic and hypoxic conditions when HIF-1 $\alpha$ expression was knocked down $(\mathrm{P}<0.001$, Fig. $8 \mathrm{C})$, suggesting that HIF-1 $\alpha$ mediated both U251 and Hep3B cell invasion. These results demonstrate that F2 has strong effect upon inhibiting cell invasion through downregulation of HIF-1 $\alpha$ expression.

\section{Discussion}

Regarding the novel F2 natural antitumor product we extracted, studies to date have shown that it may be a potential antitumor agent, which have multiple antitumor effects through various signaling pathways involved in cell survival, death, migration and invasion $(8,10)$. In the present study, F2 decreased HIF-1 $\alpha$ expression in U251 and Hep3B cells mainly through disturbing the PI3K-AKT-mTOR and MAPK-ERK1/2 pathways, and finally inhibited tumor angiogenesis and cell invasion in vitro (Fig. 9). These findings provide new insights into our previous studies and potentially explain that antitumor effect of F2 may be linked to HIF-1 $\alpha$.

As the only oxygen-regulated subunit, HIF-1 $\alpha$ is highly expressed in solid tumors and regulates expression of multiple genes involved in tumorigenesis. Many studies have shown that knocking down the expression of HIF-1 $\alpha$ could significantly control the tumor growth, inhibit angiogenesis and invasion $(29,32,33)$, so we focused our study on HIF-1 $\alpha$. To date it has been shown that multiple signaling pathways are involved in the regulation of hypoxia-induced HIF-1 $\alpha$ protein stabilization and expression. To define the signaling mechanisms by which F2 inhibited hypoxia-induced HIF-1 $\alpha$ expression, we examined the effects of F2 on the activation of PI3K-AKT-mTOR and ERK1/2 pathways in U251 and Hep3B cells in response to hypoxia. Our results indicated that F2 significantly inhibited hypoxia-mediated activation of AKT, mTOR and ERK1/2 in both cell types, which were consistent with its inhibitory effects on hypoxia-induced HIF-1 $\alpha$ protein accumulation and HIF-1 $\alpha$ target gene expression. mTOR is known to regulate the HIF-1 $\alpha$ protein translation by controlling the phosphorylation of the downstream effectors P70S6K and 4E-BP1 (34). We found that F2 could inhibit the hypoxia-induced P70S6K and 4E-BP1 in U251 and Hep3B cell lines. Collectively, these findings suggest that F2 probably inhibits HIF-1 $\alpha$ translation by blocking the activation of PI3K/AKT-mTOR and ERK1/2 pathways.

EGFR might increase the cellular response to hypoxia by increasing HIF-1 $\alpha$ expression (35). The anti-EGFR antibody, cetuximab, can sensitize human head and neck squamous cell carcinoma cells to radiation in part through inhibiting radiation-induced HIF-1 $\alpha$ (36). In our study, we demonstrated for the first time that both hypoxia and EGF could induce the expression of HIF-1 $\alpha$ and VEGF in both cells by activation of EGFR. F2 was able to inhibit the expression of HIF-1 $\alpha$ in both cell lines induced by hypoxia or EGF. These results indicate 
that EGFR is a regulator of HIF-1 $\alpha$ in both U251 and Hep3B cells, and may also be a potential target of F2, but the latter speculation needs further study.

Overexpression of HIF-1 $\alpha$ has been found to be closely related with tumor angiogenesis and invasion (26,37). F2 could inhibit the hypoxia-simulated tumor angiogenesis and cell invasion in vitro in a HIF-1 $\alpha$-dependent manner, and MMP-2 may be the key protein participating in the inhibitory effect of F2 on cell invasion because it could be involved in the breakdown of the extracellular matrix (31). However, there are other proteins participating in the hypoxia-induced tumor invasion, such as CXC chemokine receptor 4 (CXCR4) and interleukin-8 (IL-8) $(38,39)$. Accordingly, additional studies are underway to identify the associated genes that are directly or indirectly involved in the inhibitory effect of F2 on tumor cell invasion in response to hypoxia and/or HIF-1 $\alpha$ overexpression.

Under hypoxic conditions, HIF-1 $\alpha$ is stabilized and forms heterodimers with constantly-expressed HIF-1 $\beta$. It is the current opinion that hypoxia has no effect on the levels of HIF-1 $\beta(40,41)$. So we and most other researchers only focus our study on the oxygen-regulated HIF-1 $\alpha$ subunit. However, in our study, hypoxia (16 h) also slightly induced the expression of HIF-1 $\beta$ in both U251 and Hep3B cells. F2 also inhibited the expression of HIF-1 $\beta$ protein under normoxic and hypoxic conditions in accordance with HIF-1 $\alpha$. A study published recently reported that hypoxia might induce the expression of HIF-1 $\beta$ in Hep3B cell lines by inducing the expression of HIF- $1 \alpha$, but this relation is cell-type specific and not widely existing in tumor cells (42). Hence, it is speculated that F2 may decrease the level of HIF-1 $\beta$ by inhibiting HIF-1 $\alpha$ expression, and HIF-1 $\beta$ should be further investigated, especially regarding tumorigenesis, because $\mathrm{HIF}-1 \beta$ regulation is far more complex than appreciated today.

In conclusion, we have shown for the first time that F2 decreased HIF-1 $\alpha$, VEGF and MMP-2 expression in U251 and Hep3B cells mainly through interfering with PI3K-AKTmTOR and ERK1/2 pathways, leading to inhibition of tumor angiogenesis and cell invasion in vitro.

\section{Acknowledgements}

We are grateful to Dr Giovanni Melillo for his generous gift of the U251-HRE, U251-pGL3 cell lines and the pGL2-TK-HRE plasmid. This study was partially supported by the National Natural Science Foundation of China (no. 30973560) and National High Technology Research and Development Program of China (863 Program) (no. 2012AA020305).

\section{References}

1. Melillo G: Targeting hypoxia cell signaling for tumor therapy. Cancer Metastasis Rev26: 341-352, 2007.

2. Semenza GL: HIF-1 and tumor progression: pathophysiology and therapeutics. Trends Mol Med 8: 62-67, 2002.

3. Semenza GL: Targeting HIF-1 for tumor therapy. Nat Rev Cancer 3: $1-11,2003$

4. Semenza GL: HIF-1: upstream and downstream of tumor metabolism. Curr Opin Genet Dev 20: 51-56, 2010.

5. Sun BS, Belchior GP, Ricardo da Silva JM and Spranger MI: Isolation and purification of dimeric and trimeric procyanidins from grape seeds. J Chromatogr A 841: 115-121, 1999.
6. Sun BS, Leandro C, Ricardo da Silva JM and Spranger MI: Separation of grape and wine proanthocyanidins according to their degree of polymerization. J Agr Food Chem 46: 1390-1396, 1998.

7. Spranger MI, Sun BS, Mateus A, et al: Chemical characterization and antioxidant activities of oligomeric and polymeric procyanidin fractions from grape seeds. Food Chem 108: 519-532, 2008.

8. Huang M, Sun BS, Zhao YQ, et al: Effects of catechin and its polymers on ethanol-induced ascorbic acid and hydroxyl radical release in mouse striatum. J Chin Nat Med 1: 34-40, 2003.

9. Zhang FJ, Yang JY, Mou YH, et al: Inhibition of U-87 human glioblastoma cell proliferation and formyl peptide receptor function by oligomer procyanidins (F2) isolated from grape seeds. Chem Biol Interact 179: 419-429, 2009.

10. Yang JY, Wang Q, Zhao RJ, et al: Identification of oligomer proanthocyanidins (F2) isolated from grape seeds as a formyl peptide receptor 1 partial agonist. Int Immunopharmacol 15: 756-763, 2013.

11. Huang J, Chen K, Chen J, et al: The G-protein-coupled formylpeptide receptor FPR confers a more invasive phenotype on human glioblastoma cells. Br J Cancer 102: 1052-1060, 2010.

12. Liu Y, Huang J, Zhou Y, et al: The role of chemo-attractant receptors in the progression of glioma. INTECH 21: 286-305, 2011.

13. Guo L, Wang LH, Sun BS, et al: Direct in vivo evidence of protective effects of grape seed procyanidin fractions and other antioxidants against ethanol-induced oxidative DNA damage in mouse brain cells. Food Chem 55: 5881-5891, 2007.

14. Liu Y, Li YM, Tian RF, et al: The expression and significance of HIF- $1 \alpha$ and GLUT-3 in glioma. Brain Res 1304: 149-154, 2009.

15. Zhang HF, Qian DZ, Tan YS, et al: Digoxin and other cardiac glycosides inhibit HIF-1 $\alpha$ synthesis and block tumor growth. Proc Natl Acad Sci USA 105: 19579-19586, 2008.

16. Rapisarda A, Uranchimeg B, Scudiero DA, et al: Identification of small molecule inhibitors of hypoxia-inducible factor-1 transcriptional activation pathway. Cancer Res 62: 4316-4324, 2002.

17. Xia MH, Bi K, Huang RL, et al: Identification of small molecule compounds that inhibit the HIF-1 signaling pathway. Mol Cancer 8: 1-13, 2009.

18. Chau NM, Rogers P, Aherne W, et al: Identification of novel small molecule inhibitors of hypoxia-inducible factor- 1 that differentially block hypoxia-inducible factor-1 activity and hypoxia-inducible factor-1 $\alpha$ induction in response to hypoxic stress and growth factors. Cancer Res 65: 4918-4928, 2005.

19. Zhao Y, Wu JH, Wu SP, et al: A recombinant cell-permeable p53 fusion protein is selectively stabilized under hypoxia and inhibits tumor cell growth. Cancer Lett 279: 101-107, 2009.

20. Kamat CD, Green DE, Warnke L, et al: Mutant p53 facilitates pro-angiogenic, hyper-proliferative phenotype in response to chronic relative hypoxia. Cancer Lett 249: 209-219, 2007.

21. Zeng M, Xiao F, Zhong X, et al: Reactive oxygen species play a central role in hexavalent chromium-induced apoptosis in Hep3B cells without the functional roles of p53 and caspase-3. Cell Physiol Biochem 32: 279-290, 2013.

22. Kizaka-Kondoh S, Kuchimaru T and Kadonosono T: Pathophysiological response to hypoxia-from the molecular mechanisms of malady to drug discovery: hypoxia-inducible factor-1 (HIF-1) active cells as a target for tumor therapy. J Pharmacol Sci 115: 440-445, 2011.

23. Jung HJ, Park JW, Lee JS, et al: Silibinin inhibits expression of HIF- $1 \alpha$ through suppression of protein translation in prostate tumor cells. Biochem Biophys Res Commun 390: 71-76, 2009.

24. Jung HJ, Suh SI, Suh MH, et al: Pentamidine reduces expression of hypoxia-inducible factor- $1 \alpha$ in DU145 and MDA-MB-231 tumor cells. Cancer Lett 303: 39-46, 2011.

25. Karar J and Maity A: PI3K/AKT/mTOR pathway in angiogenesis. Front Mol Neurosci 4: 1-8, 2011.

26. Zhong H, Chiles K, Feldser D, et al: Modulation of hypoxiainducible factor $1 \alpha$ expression by the epidermal growth factor/ phosphatidylinositol 3-kinase/PTEN/AKT/FRAP pathway in human prostate cancer cells: implications for tumor angiogenesis and therapeutics. Cancer Res 00: 1541-1545, 2000.

27. Ban HS, Uno M and Nakamura H: Suppression of hypoxiainduced HIF-1 $\alpha$ accumulation by VEGFR inhibitors: different profiles of AAL993 versus SU5416 and KRN633. Cancer Lett 296: 17-26, 2010. 
28. Zhang QZ, Tang XD, Lu QY, et al: Green tea extract and (-)-epigallocatechin-3-gallate inhibit hypoxia- and seruminduced HIF-1 $\alpha$ protein accumulation and VEGF expression in human cervical carcinoma and hepatoma cells. Mol Cancer Ther 5: 1227-1238, 2010.

29. Medici D and Olsen BR: Rapamycin inhibits proliferation of hemangioma endothelial cells by reducing HIF-1-dependent expression of VEGF. PLoS One 7: e42913, 2012.

30. Namiki A, Brogi E, Kearney M, et al: Hypoxia induces vascular endothelial growth factor in cultured human endothelial cells. J Biol Chem 270: 31189-31195, 2010.

31. Fujiwara S, Nakagawa K, Harada $\mathrm{H}$, et al: Silencing hypoxiainducible factor- 1 inhibits cell migration and invasion under hypoxic environment in malignant gliomas. Int $\mathbf{J}$ Oncol 30: 793-802, 2010

32. Lu JM, Zhang KQ, Chen S and Wen W: Grape seed extract inhibits VEGF expression via reducing HIF-1 $\alpha$ protein expression. Carcinogenesis 30: 636-644, 2009.

33. Manolescu B, Oprea E, Busu C and Cercasov C: Natural compounds and the hypoxia-inducible factor (HIF) signaling pathway. Biochimie 91: 1347-1358, 2009.

34. Wullschleger S, Loewith R and Hall MN: TOR signaling in growth and metabolism. Cell 124: 471-484, 2006.

35. Swinson DE and O'Byrne KJ: Interactions between hypoxia and epidermal growth factor receptor in non-small-cell lung tumor Clin Lung Cancer 7: 250-256, 2006.
36. Lu HQ, Liang K, Lu Y and Fan Z: The anti-EGFR antibody cetuximab sensitizes human head and neck squamous cell carcinoma cells to radiation in part through inhibiting radiationinduced upregulation of HIF-1 $\alpha$. Cancer Lett 322: 78-85, 2012.

37. Cheung W, Wellman TL and Lounsbury KM: VEGF and HIF-1a expression are increased in advanced stages of epithelial ovarian tumor. Gynecol Oncol 91: 513-517, 2003.

38. Ahn JK, Koh EM, Cha HS, et al: Role of hypoxia-inducible factor-1 in hypoxia-induced expressions of IL-8, MMP-1 and MMP-3 in rheumatoid fibroblast like. Rheumatology 47: 834-839, 2003.

39. Wang XB, Li CX, Chen Y, et al: Hypoxia enhances CXCR4 expression favoring microglia migration via HIF-1 $\alpha$ activation. Biochem Biophys Res Commun 371: 283-288, 2008.

40. Berchner Pfannschmidt U, Frede S, Wotzlaw C and Fandrey J: Imaging of the hypoxia-inducible factor pathway: insights into oxygen sensing. Eur Respir J 32: 210-217, 2008.

41. Semenza GL: Hypoxia-inducible factors in physiology and medicine. Cell 148: 399-408, 2012.

42. Wolff M, Jelkmann W, Dunst J and Depping R: The aryl hydrocarbon receptor nuclear translocator (ARNT/HIF-1 $\beta$ ) is influenced by hypoxia and hypoxia-mimetics. Cell Physiol Biochem 32: 849-858, 2013. 